\title{
Wkład doktryn religijnych w kształtowanie postaw pro-środowiskowych
}

\section{Wprowadzenie}

Jeszcze do niedawna człowiek był przekonany, że narastającym problemom ekologicznym można zaradzić przy pomocy samych tylko środków technicznych i technologicznych. Jednak wraz z gwałtownym pogarszaniem się stanu środowiska naturalnego zdano sobie sprawę, że działania technologiczne muszą być uzupełnione o rzetelną refleksję filozoficzną, która wskaże źródła kryzysu ekologicznego.

W latach 60. i 70. XX w. dokonała się znacząca przemiana w sposobie patrzenia na problemy środowiskowe. Ówczesna refleksja filozoficzna nad kryzysem ekologicznym była już na tyle dojrzała, że doprowadziła do ukonstytuowania się filozofii ekologicznej i etyki środowiskowej ${ }^{1}$. Ważnym katalizatorem takiej refleksji było ogłoszenie w 1972 r. tzw. pierwszego raportu Klubu Rzymskiego. Apokaliptyczna wizja świata wyłaniająca się z raportu skłoniła wielu filozofów do pogłębionego namysłu nad stosunkiem człowieka do środowiska naturalnego oraz znalezienia sposobu takiego kształtowania postaw człowieka, by były one przyjazne przyrodzie ${ }^{2}$.

Szukając rzetelnej diagnozy kryzysu ekologicznego wskazywano na postawy aksjologiczne współczesnego człowieka, jego przekonania religijne, teorie naukowe oraz filozoficzne, na fundamencie których rozwinęła się dwudziestowieczna cywilizacja industrialna w swojej wersji kapitalistycznej i socjalistycznej.

Poddano wówczas dogłębnej krytyce idee religijne, filozoficzne, moralne, ekonomiczne i polityczne, które stanowiły podstawę tej cywilizacji. Próbowano je zastąpić takimi koncepcjami filozoficznymi i przekonaniami religijnymi, które przywróciłyby harmonijną koegzystencję człowieka i przyrody. Uznano, że najskuteczniejszą strategią przeciwdziałania kryzysowi ekologicznemu jest zmiana

Por. W. Tyburski, Powstanie i rozwój filozofii ekologicznej, „Problemy Ekorozwoju” 1(2006)1, s. 8.

2 Por. I. S. Fiut, Prekursorzy myślenia ekofilozoficznego, w: I. S. Fiut red., Idee i Myśliciele. Środowiskowe i społeczne problemy filozofii, t. 5, Kraków 2003, s. 15. 
w sferze przekonań etyczno-moralnych człowieka oraz wypracowanie spójnego systemu myślenia, który uwzględniałby zarówno interes człowieka, jak i pozostałych istot żywych wraz z ich środowiskiem życia ${ }^{3}$.

Wydaje się, że trwająca już ponad 40 lat debata filozoficzna przyczyniła się do znacznych zmian w świadomości całych społeczeństw. Wypracowano wiele alternatywnych wersji etyk środowiskowych i ujęć filozofii ekologii, które dostarczyły podstaw do proekologicznego sposobu myślenia o ekonomii i polityce. Można mieć jednak wrażenie, że ciągle zbyt mało wykorzystanym i niedocenionym uczestnikiem debaty ekologicznej jest religia.

\section{Religie partnerem debaty ekologicznej}

Po początkowym etapie obwiniania religii monoteistycznych o antropocentryzm, uznawany za podstawę braku szacunku dla przyrody oraz okresie uproszczonej gloryfikacji religii takich, jak: buddyzm, hinduizm i religie pierwotne przyszedł czas na rzetelną refleksję filozoficzną nad rolą religii w przezwyciężaniu kryzysu ekologicznego. Nie chodzi tu o refleksję teologiczną, ale o filozoficzny namysł nad możliwościami, jakie stwarza fenomen religii oraz doktryny różnych tradycji religijnych.

Liderzy światowych religii i intelektualiści reprezentujący poszczególne tradycje religijne stają obecnie wobec nowych wyzwań związanych z kryzysem ekologicznym. Chodzi zarówno o korektę naszej roli jako obywateli wszechświata, jak i ponownego odkrycia naszego miejsca w ziemskiej wspólnocie życia. Domaga się to postawienia najbardziej podstawowych pytań: „skąd przychodzimy?” oraz „dokąd zdążamy?”. Niezbędne jest przemyślenie roli człowieka w szerokim kontekście ewolucji wszechświata oraz węższym kontekście zjawiska życia na naszej planecie. Pojawiają się też pytania: czym jest historia ludzkości wobec 12 mld lat historii wszechświata? Jakie jest miejsce człowieka w trwającej 4,6 mld lat historii Ziemi? Jak możemy wspierać stabilność i integralność zjawiska życia? Odpowiedzi na te pytania niejako wymuszają włączenie religii we współczesną debatę ekologicznąa

Same religie muszą odpowiedzieć sobie na pytanie, jak mogą towarzyszyć człowiekowi w procesie przeciwdziałania degradacji środowiska przyrodniczego, odtwarzania ekosystemów i zabezpieczenia zasobów dla przyszłych pokoleń oraz w jaki sposób mogą zachęcić człowieka do ekologicznego stylu życia. Nabrzmiały kryzys ekologiczny wymusza na światowych religiach zajęcie stanowiska wobec grożącego niebezpieczeństwa. Podejmując kwestie ekologiczne, religie wchodzą

Por. tamże, s. 16-17.

4 Por. M. E. TuckeR, Worldly Wonder: Religions Enter Their Ecological Phase, „Religion East \& West" (2002)2, s. 4. 
- jak określiła to Mary Tucker - w „ekologiczną fazę” i odnajdują swój planetarny wymiar. Podobnie jak w wieku XX religie zaangażowały się w zacieranie różnic na polu społecznym, tak obecnie stają przed nowym wyzwaniem - zaangażowania na rzecz ochrony życia na Ziemi. Wydaje się także, że z koncentrowania się na relacji Bóg-człowiek oraz człowiek-człowiek, w swej „ekologicznej fazie” religie poszerzają perspektywę spoglądania na rzeczywistość o relację człowiek-Ziemia 5 .

Wejście w „ekologiczną fazę" nie jest jedynie „przestawieniem akcentów”, ale pociąga za sobą istotną transformację. Chodzi o to, by duchowe, symboliczne, rytualne i etyczne źródła ekologicznego przebudzenia religii znalazły w poszczególnych tradycjach religijnych swój pełniejszy wyraz. Wraz z tą przemianą religie będą w stanie kształtować taki styl życia swoich wyznawców, który będzie przynosił korzyści nie tylko ludziom, ale całej wspólnocie życia na Ziemi. Takie zaangażowanie religii pociąga za sobą potrzebę sprzeciwienia się niektórym aspektom dziedzictwa nowożytności. Religie będą musiały zmierzyć się z niepohamowaną konsumpcją oraz dokonać refleksji nad nowożytnym faworyzowaniem praw jednostki względem odpowiedzialności wspólnej $j^{6}$.

\section{Wkład religii w ekologiczną dyskusję z nowożytnością}

Nowożytność jest zjawiskiem kulturowym, które ma bardzo różnorodne korzenie. Można chyba stwierdzić, że nowożytność ma swoje podstawy zarówno w:

- humanistycznej rewolucji zapoczątkowanej w XIV-wiecznym Renesansie;

- odkrywczej rewolucji zainicjowanej przez XV-wieczne wyprawy eksploracyjne;

- religijnej rewolucji XVI-wiecznej Reformacji;

- naukowej rewolucji wieku XVII;

- politycznej rewolucji XVIII-wiecznego Oświecenia;

- ekonomicznej rewolucji XIX-wiecznej industrializacji

- społecznej rewolucji XX-wiecznej promocji praw człowieka.

Wszystkie te rewolucje będąc ze sobą połączone i wzajemnie się warunkując, legły u podstaw współczesnego kryzysu ekologicznego i zainicjowały tym samym kolejną rewolucję - „rewolucję ekologiczną”. Rewolucja ta rozpoczęła się pod koniec XX wieku i wszystko wskazuje na to, że zdominuje aktywność człowieka $\mathrm{w}$ wieku XXI.

Wielu uczonych twierdzi, że to myśl nowożytna, a szczególnie mentalność oświeceniowa leży zarówno u podstaw sukcesu cywilizacji Zachodu, jak i współczesnego kryzysu ekologicznego. Mentalność ta jest niezmiernie dynamiczną ideologią, zdolną do przeprowadzania zmian na skalę niebywałą w historii ludz-

\footnotetext{
Por. Tamże, s. 4-5.

6 Por. Tamże, s. 5.
} 
kości . Religie stwarzają możliwość przezwyciężenia projektu oświeceniowego przez jego poszerzenie i rozwinięcie zaniedbanego poczucia wspólnoty ${ }^{8}$. Tu Weiming uważa, że dla zmiany naszego modelu życia konieczne jest wykorzystanie trzech rodzin tradycji duchowych: (1) etyczno-religijnej tradycji nowożytnego Zachodu, szczególnie: filozofii greckiej, judaizmu oraz chrześcijaństwa; (2) duchowej tradycji takich religii, jak hinduizm, jainizm i buddyzm (Azja południowa i południowowschodnia), konfucjanizm i taoizm (Azja wschodnia) oraz islam; a także (3) pierwotnych tradycji religijnych rodzimych mieszkańców obu Ameryk, Hawajów, Maori (Nowa Zelandia - Wschodnia Polinezja) oraz licznych plemiennych tradycji religijnych sięgających neolitu9.

Jako beneficjenci i jednocześnie ofiary mentalności oświeceniowej wykazujemy wierność naszemu dziedzictwu przez jego wzbogacanie i przekształcanie, bazując na tych trzech duchowych źródłach. I chociaż tradycje religijne znacząco się różnią w swoich koncepcjach etycznych i stosunku do świata, to jednak stanowią bogaty potencjał inspirujący nas do szukania drogi wyjścia z niebezpieczeństwa, jakie grozi światu ${ }^{10}$.

Zderzenie się różnych prądów nowożytności z różnymi tradycjami religijnymi postawiło przed religią znaczące wyzwania. Renesansowy humanizm zmienił sposób patrzenia na świat z teocentrycznej perspektywy średniowiecznej, na perspektywę antropocentryczną. Odkrycia geograficzne musiały nieuchronnie doprowadzić do konfrontacji między kulturami i religiami. Reformacja stanowiła poważne wyzwanie dla dominującego Kościoła katolickiego w kwestii jego doktryny i roli jednostki w interpretacji Biblii oraz osobistej drogi zbawienia. Oświeceniowe przeciwstawienie wiary i rozumu, zakwestionowanie religijnej kosmologii, pojawienie się darwinowskiej teorii ewolucji, agresywny konsumpcjonizm oraz współczesna promocja sekularystycznego humanizmu, zmuszają religie do poważnych przemyśleń i rzetelnej debaty nad dobrodziejstwami i zagrożeniami nowożytności ${ }^{11}$.

Wydaje się, że refleksja nad wypracowaniem przez współczesnego człowieka pro-środowiskowych postaw musi zacząć się od odrzucenia niekwestionowanych założeń będących dziedzictwem nowożytności. Bez tego nie da się zbudować zrównoważonego modelu rozwoju społeczeństwa. Gary Gardner wymienia 7 fałszywych założeń, wskazując, że jak najszybciej należałoby je odrzucić: ${ }^{12}$

Por. Tu Wei-ming, Beyond the Enlightenment Mentality, [w:] M. E. Tucker, J. A. Grim red., Worldviews and Ecology. Religion, Philosophy, and the Environment, Orbis Books, Maryknoll 1994, s. 21.

8 Por. Tamże, s. 25.

9 Por. Tamże, s. 25-28.

10 Por. Tamże, s. 28.

11 Por. M. E. Tucker, Worldly Wonder..., art. cyt., s. 7-8.

12 Por. G. T. Gardner, Inspiring Progres. Religions' Contributions to Sustainable Development, W W Norton \& Company, New York - London 2006, s. 21. 
1) Jedynym celem ekonomii jest generowanie zysku;

2) Gromadzenie dóbr jest głównym celem życia;

3) Marnotrawstwo jest nieuniknione w bogatych społeczeństwach;

4) Masowa bieda, chociaż pożałowania godna, jest nieuchronną częścią życia;

5) Środowisko jest dodatkiem do ekonomii;

6) Gatunki i ekosystemy mają znaczenie dla ekonomii i estetyki, ale nie mają wartości same z siebie;

7) Etyka nie odgrywa znaczącej roli w tworzeniu postępu.

Większość tych „prawd” leży w centrum zainteresowania wielu tradycji religijnych i wkład religii w ich przezwyciężenie jest nie do przecenienia.

W wyniku stawianych przez różne nowożytne nurty wyzwań, religie dysponują bogatym doświadczeniem oraz potencjałem intelektualnym, które czynią z nich partnera mogącego owocnie przyczynić się do współczesnej debaty nad konsekwencjami nowożytności. Są także w stanie pomóc w przezwyciężeniu negatywnych jej skutków leżących u podstaw kryzysu ekologicznego.

Zachodnia nowożytność promująca indywidualizm, demokrację, naukę, racjonalizm i kapitalizm rozszerzyła się obecnie na Azję, Afrykę i Amerykę Łacińską, tworząc nowe formy ekonomicznego, politycznego i społecznego postępu. Ujawniają się jednak pewne braki nowożytności w postaci redukcjonistycznej nauki, utylitarnej ekonomii, nadętego indywidualizmu i opartej na zysku polityce. Wydaje się, że w tej sytuacji perspektywa przymierza między religią i ekologią może przynieść wiele korzyści. Doceniając pozytywny wpływ nowożytności i opierając się na swoich bogatych podstawach etycznych, religie mogą skutecznie sprzeciwić się niefrasobliwości dzisiejszego postępu, który niszczy ekosystemy i wyczerpuje zasoby naturalne ${ }^{13}$.

Wyobcowanie człowieka względem przyrody jest szczególnie widoczne w wielomilionowych społecznościach miejskich, które wskutek bezrefleksyjnego używania techniki zatraciły poczucie duchowego wymiaru przyrody oraz świadomość zależności od środowiska przyrodniczego. Jak wskazują niektórzy uczeni, nadzieję na przezwyciężenie alienacji człowieka względem przyrody niesie religia, która dostarcza człowiekowi motywacji do walki z kryzysem ekologicznym $^{14}$. U podstaw tego kryzysu leży bowiem kryzys duchowy i etyczny, który boleśnie dotyka współczesnego człowieka ${ }^{15}$.

13 Por. M. E. Tucker, Worldly Wonder..., art. cyt., s. 9.

14 Por. T. Berry, The Dream of the Earth, Sierra Club Books, New York 1990, s. 24-25.

15 Por. Jan Pawe£ II, Encyklika Centesimus Annus, nr 37; por. także S. H. Nasr, Religion and the Order of Nature, Oxford University Press 1996, s. 193. 


\section{Religie dostarczają motywacji do walki z kryzysem ekologicznym}

Wielu intelektualistów i liderów reprezentujących różne tradycje religijne zabrało już głos przeciw destrukcyjnym konsekwencjom postępu, szukając sprzymierzeńców wśród tych, którzy dostrzegli niebezpieczeństwa wynikające z nieograniczonego wzrostu ekonomicznego, nieokiełznanej konsumpcji oraz nadużywania zasobów naturalnych. Ludzie religii dostrzegają zagrożenia, które wynikają z poddania się temu trendowi w postaci stopniowej laicyzacji oraz utraty twórczych dążeń człowieka.

Obserwuje się, że w krajach rozwiniętych poszukiwanie sensu życia zastępuje się promocją materializmu, natomiast w krajach rozwijających się sens życia jest zastępowany rozwojem ekonomicznym za wszelką cenę. Świat przyrody i świat człowieka degradują się w wyścigu do nieograniczonego ekonomicznego postępu. Konieczne są radykalne zmiany w stylu życia współczesnego człowieka. Religie ze swoim moralnym autorytetem oraz wielowiekowym doświadczeniem w kształtowaniu ludzkich postaw są ważnym sojusznikiem w przeciwdziałaniu tym tendencjom i promowaniu takiego stylu życia, który nie skupiałby się na konsumpcji i gromadzeniu dóbr. Z całą pewnością religie są w stanie wskazać człowiekowi wyższe aspiracje niż materialny dobrobyt i w tym sensie są naturalnym sprzymierzeńcem w przeciwdziałaniu ekologicznej katastrofie ${ }^{16}$.

Wraz z narastaniem kryzysu ekologicznego i zainteresowaniem się tą kwestią przez filozofów, intelektualiści reprezentujący poszczególne tradycje religijne, szczególnie teolodzy chrześcijańscy, włączyli się w refleksję nad przyczynami kryzysu środowiskowego, analizując go w ramach własnych systemów teologicznych. Obecnie zauważa się jednak nową tendencję.

\section{Filozoficzna refleksja nad rolą religii w debacie ekologicznej}

Oprócz refleksji teologicznej, coraz częściej mamy do czynienia z filozoficzną i religiologiczną refleksją nad rolą i możliwościami religii we współczesnej debacie ekologicznej. Przykładem takiej właśnie refleksji jest działalność amerykańskich naukowców Mary Evelyn Tucker i Johna Grima. Wraz z licznym gronem uczonych z całego świata postanowili oni włączyć do walki z kryzysem ekologicznym ogromny potencjał drzemiący w światowych religiach. W latach 19961998 zorganizowali kilkanaście konferencji naukowych prezentujących stosunek poszczególnych religii do środowiska naturalnego. W konferencjach tych wzięło udział ponad 600 wybitnych uczonych i teologów ze wszystkich najważniejszych religii świata. Zainteresowanie, z jakim spotkały się sympozja oraz wydana przez Harvard University Press seria wydawnicza Religions of the World and Ecology,

16 Por. M. E. Tucker, Worldly Wonder..., art. cyt., s. 9. 
spowodowały, że dla kontynuacji filozoficznych badań na styku religii i ekologii powstało w roku 1998 na Harvardzie Forum on Religion and Ecology ${ }^{17}$.

Aktualnie Mary Tucker i John Grim przenieśli działalność forum na Yale University, gdzie w ramach studiów interdyscyplinarnych prowadzą Yale Religion and Ecology Program, będący nowatorską, komplementarną refleksją ekologiczną uwzględniającą rolę i możliwości religii w debacie ekologicznej.

Mary Tucker przyznaje, że głównym celem Forum on Religion and Ecology jest wypracowanie nowej dyscypliny naukowej określanej najczęściej jako „religion and ecology"18. Duże zainteresowanie tą tematyką przyczyniło się do otwarcia w 2001 r. przez University of Florida studiów doktoranckich ze specjalności Religion and Ecology $y^{19}$.

Kolejnym krokiem w rozwoju debaty filozoficznej nad zagadnieniami na styku religii, środowiska naturalnego i kultury było powstanie w roku 2006 International Society for the Study of Religion, Nature and Culture. O popularności podejmowanej tematyki i dynamizmie rozwoju tego towarzystwa naukowego świadczy fakt, że na koniec 2008 roku liczyło ono już 215 uczonych reprezentujących bardzo różnorodne środowiska naukowe ${ }^{20}$.

\section{Podsumowanie}

Wkroczenie religii w „ekologiczną fazę” stwarza nadzieję na skuteczną zmianę stylu życia i zaangażowania całych społeczeństw w działalność pro-środowiskową. Liczne inicjatywy uczonych oraz polityków wzywających liderów religijnych do współdziałania na rzecz walki z kryzysem ekologicznym zdają się przynosić rezultaty. Religie włączyły się w refleksję nad genezą problemów środowiska naturalnego oraz podjęły konkretne działania na rzecz ochrony przyrody. Działania te oprócz społecznego lobbingu, publicznych wystąpień, edukacji środowiskowej i szeroko pojętej promocji pro-środowiskowego stylu życia przyjęły także formę konkretnych akcji na rzecz ochrony przyrody.

Oprócz niewątpliwych pozytywów wypływających z ekologicznego zaangażowania się religii, powstają jednak pewne wątpliwości i niebezpieczeństwa. Pojawia się pokusa stworzenia jednej „ekologicznej religii”, która byłaby zlepkiem

17 Oficjalna witryna internetowa Forum on Religion and Ecology: <www.religionandecology.org>, (data dostępu: 30.06.2009).

18 Por. M. E. Tucker, Worldly Wonder..., art. cyt., s. 11.

19 Por. B. Monserud, Religion and Ecology: Visions or an Emerging Academic Field Consultation Report, "Worldviews: Environment Culture Religion" 6(2002)1, s. 81-93; por. także R. C. FoLTZ, Nature in Asian Traditions: the State of the Field, "Worldviews: Environment Culture Religion" 10(2006)1, s. 1-4.

20 Por. The International Society for the Study of Religion, Nature \& Culture, «http://www. religionandnature.com/society/index.htm», (data dostępu: 30.05.2009). 
wybranych elementów pochodzących z różnych tradycji religijnych. Taki religijny synkretyzm oraz elementy New Age obecne we współczesnej kulturze mogą być niebezpieczne dla tożsamości samych religii. W konsekwencji religie tracąc tożsamość, mogą utracić swą wewnętrzną, duchową siłę niezbędną do ukierunkowywania i motywowania swych wiernych do określonych działań.

Ekologiczny potencjał religii jest dziś oczywisty. Intelektualne i strukturalne możliwości poszczególnych tradycji religijnych są nie do przecenienia. Wydaje się jednak, że potrzebna jest pogłębiona refleksja nad sposobami ekologicznego zaangażowania religii, która przyniesie pożytek zarówno środowisku, jak i religiom oraz ich wyznawcom. Rola religii w przeciwdziałaniu kryzysowi ekologicznemu jest istotna i chociaż religie nie rozwiążą kryzysu, to jednak ubogacają i uzupełniają dotychczasowe działania człowieka w walce z kryzysem ekologicznym.

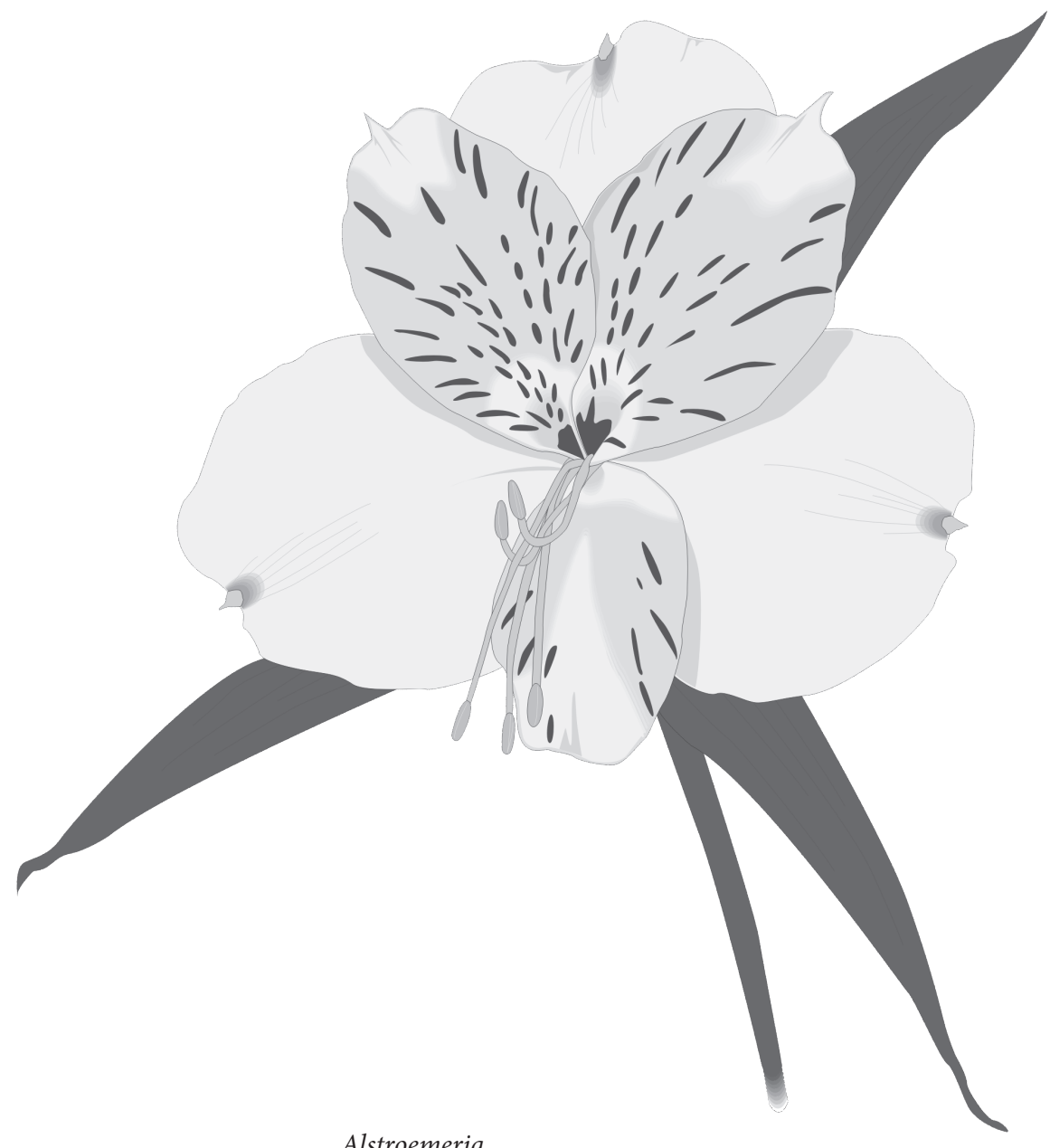

Alstroemeria 